\title{
Service Quality In Accounting Firms: The Relationship Of Service Quality To Client Satisfaction And Firm/Client Conflict
}

\author{
Carl L. Saxby, (E-mail: csaxby@usi.edu), University of Southern Indiana \\ Craig R. Ehlen, (E-mail: cehlen@usi.edu), University of Southern Indiana \\ Timothy R. Koski, (E-mail: tkoski@mtsu.edu), Middle Tennessee State University
}

\begin{abstract}
This paper presents the results of a study using the marketing-based SERVQUAL scale to examine the relationship between service quality and both client satisfaction and firm/client conflict in an accounting firm setting. Using a sample of 154 clients, we confirm that service quality is positively related to clients' satisfaction with their accounting firm and negatively related to firm/client conflict. We also examine the individual dimensions of service quality to provide insight into specific steps accounting firms can take both to increase client satisfaction and to decrease firm/client conflict.
\end{abstract}

\section{Introduction}

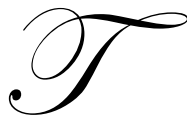

he marketing literature has long been cognizant that service quality can contribute to success among competing service providers. In fact, Hoffman and Bateson (1997, p. 299) suggest that where there are many firms offering nearly identical services within a limited geographic area, "establishing service quality may be the only way of differentiating oneself." Accounting is a service based on rules and regulations that are identical from one business to another, and generally there are many potential accounting firms within a limited geographic area. Thus, providing high levels of service quality - as perceived by clients - is a critical strategic goal for accounting firms.

Measuring service quality is important to accounting firms because higher levels of service quality are associated with higher levels of customer satisfaction. Higher levels of customer satisfaction lead, in turn, to repeat business and ultimately to higher levels of income. Thus, accounting firms should be concerned with maximizing service quality. Accounting firms should be particularly concerned about clients' perceptions of service quality in light of the negative publicity the profession received concerning Arthur Andersen's role in the collapse of Enron Corporation.

One measure of service quality frequently used in marketing research is the SERVQUAL scale (Parasuraman, Berry, and Zeithaml, 1988), which measures five different dimensions of service quality. This paper reports the results of a study using the SERVQUAL scale to examine the relationship between service quality and two important attributes of the accounting firm/client relationship: client satisfaction and firm/client conflict. We find that service quality is positively related to client satisfaction and negatively related to firm/client conflict. We also examine the individual components of the SERVQUAL scale to provide insight into what accounting firms can do both to improve client satisfaction and to decrease firm/client conflict.

\section{Literature Review And Research Questions}

The conceptual model of service quality (Parasuraman, Zeithaml, and Berry, 1985) explains the quality of service received in terms of "gaps." While five potential gaps are identified in the model, only one - the service gap - is particularly relevant in the current research. The relevant service gap is any difference between the customers' 
perceptions of the quality of service actually delivered and their prior service quality expectations. Essentially, early service quality theory held that people form expectations a priori and then compare the perceived actual performance to their prior expectations. When expectations exceed performance - a negative gap - there is dissatisfaction from low perceived service quality. A very close match of expectations to performance produces perceived service quality and satisfaction. A positive gap - performance exceeding expectations - generates customer delight. More recent research has shown that perceived performance alone is an accurate predictor of service quality and satisfaction (Cronin and Taylor, 1992; Teas, 1994).

The SERVQUAL scale (Parasuraman, Berry, and Zeithaml, 1988) measures five dimensions of service quality using two similar 22-item sections that record customers' expectations and perceptions, respectively. The five dimensions of service quality measured by the SERVQUAL scale encompass tangible aspects (service personnel and physical facilities appear neat and professional), reliability factors (ability to meet deadlines and produce error-free results), responsiveness (prompt service, employees willing to help immediately), assurance levels (adequate technical knowledge, secure transactions, inspires confidence), and empathy factors (gives personal attention, operates at convenient hours). Because of concerns regarding the length of the scale and research results showing that perceived performance alone is an accurate predictor of quality and satisfaction (Cronin and Taylor, 1992; Teas, 1994), we used only the portion of the instrument measuring clients' perceptions regarding service quality in the current research. The 22-item SERVQUAL scale used in this research is set forth in Exhibit 1.

Exhibit 1 SERVQUAL Scale

\begin{tabular}{|l|l|}
\hline Dimension of Service Quality & Components of Service Quality Dimension - Actual Questions Asked \\
\hline Tangible & My CPA firm has up-to-date-equipment \\
& My CPA firm's physical facilities are visually appealing. \\
& My CPA firm's employees are well dressed and appear neat. \\
The appearance of the physical facilities of my CPA firm is in keeping with the type of & services provided.
\end{tabular}

The SERVQUAL scale has been used extensively in marketing research. Researchers recently have begun to adapt the SERVQUAL scale to accounting. Freeman and Dart (1993), Bojanic (1991), and Weekes, Scott, and Tidwell (1996) adapted versions of the SERVQUAL scale to accounting and found that all five dimensions of the scale were relevant to client perceptions of service quality. Similarly, Turner, Aldhizer, and Shank (1999) adapted the SERVQUAL scale to study client perceptions of management advisory services (MAS) quality and found that the model was a viable method of assessing the quality of MAS provided by CPA firms. Our research addresses client satisfaction with service areas (audit, consulting, tax, and financial statement preparation) typically provided by CPA firms. 
Consistent with previous research, we predict that clients' perceptions of service quality, as measured by the SERVQUAL scale, are positively associated with client satisfaction. As stated in the null form:

H1: Clients' perceptions of service quality are positively related to client satisfaction in an accounting firm setting.

We also undertook an in-depth examination of the individual items comprising the SERVQUAL scale to determine which dimensions of service quality were most important to client satisfaction in an accounting firm setting. We then examined those dimensions of service quality found to be most associated with client satisfaction and tested the significance of each item comprising the significant dimensions. Knowing the details of which items in a particular dimension clients perceive as important will assist accounting firms in establishing specific policies designed to improve client satisfaction.

We also examined whether service quality is related to accounting firm/client conflict. Conflict in a channel relationship has been defined in various ways. Bowersox, Cooper, Lambert and Taylor (1980) define conflict as "a situation in which one member of the channel perceives another member as engaging in behavior designed to injure, thwart, or gain resources at its expense." Excessive conflict is detrimental to channel relationships. This makes it important to manage conflict so that it stays within a functional level. We hypothesize that clients' perceptions of service quality, as measured by the SERVQUAL scale, are negatively related to firm/client conflict. As stated in the null form:

H2: Clients' perceptions of service quality are negatively related to firm/client conflict in an accounting firm setting.

Similar to our analysis of the relationship between service quality and client satisfaction, we undertook an in-depth examination of the individual items comprising the SERVQUAL scale to determine which dimensions of service quality had the biggest impact on accounting firm/client conflict. We then examined those dimensions of service quality found to be most associated with firm/client conflict and tested the significance of each item comprising the significant dimensions.

\section{Methodology}

This research was conducted by mail survey. The survey instrument was developed by the researchers and designed to gather information on customers' perceptions regarding their satisfaction with the quality of service provided by their accounting firm. As discussed earlier, recent research has shown that perceived performance alone is an accurate predictor of service quality and satisfaction (Cronin and Taylor, 1992; Teas, 1994). Therefore, the survey instrument contained 22 questions regarding clients' perceptions of the five dimensions of service quality that comprise the SERVQUAL scale (Parasuraman, Zeithaml and Barry, 1985) (see Exhibit 1). Each of these items was measured on a five-point Likert-type scale.

We also collected information on client satisfaction and accounting firm/client conflict. Respondents' answers to the following five questions, as measured on a five-point Likert-type scale, were designed to provide multiple measures of client satisfaction: (1) "In general, I am pretty satisfied with my CPA firm," (2) "Overall, my CPA firm is a good company to do business with," (3) "I want to retain my CPA firm," (4) "Overall, my CPA firm's policies and programs benefit my company," and (5) "Overall, my CPA firm is very fair."

Respondents also were asked whether they felt (1) anger, (2) frustration, (3) resentment, or (4) hostility as they reflected on their relationship with their CPA firm. Respondents' answers to these four questions, as measured on a five-point Likert-type scale, were designed to provide multiple measures of accounting firm/client conflict. The survey instrument also included questions for demographic and classification purposes.

The survey was mailed to all 292 sole proprietorship, partnership, and corporate clients of a large regional accounting firm. (Clients that were either estates or trusts and clients for whom preparing personal federal or state 
income tax returns was the only professional service rendered were not included in the sample.) The survey was addressed to the primary client contact person for coordinating professional services with the accounting firm. A second request was sent to non-respondents one month after the original survey was mailed. Usable responses were received from 154 clients, a response rate of $53 \%$.

\section{Sample Characteristics}

The 154 clients included in data analysis are a representative sample of the accounting firm's clients. As shown in Tables 1 and 2, the sample contained a wide range of industries and client sizes.

\section{Table 1 Industry of Participating Clients}

$\underline{\text { Industry }}$

Manufacturing

Construction

Wholesale/Retail

Not-for-profit

Health care

Other

Missing data Total

\begin{tabular}{rr} 
Number & Percent \\
\hline 17 & 11.0 \\
20 & 13.0 \\
46 & 29.9 \\
18 & 11.7 \\
9 & 5.8 \\
42 & 27.3 \\
$\underline{2}$ & 1.3 \\
$\underline{\underline{154}}$ & $\underline{\underline{100.0}}$ \\
\hline
\end{tabular}

\section{Table 2 Size of Participating Clients}

Annual Revenue

Less than $\$ 500,000$

$\$ 500,001$ - $\$ 2,000,000$

$\$ 2,000,001-\$ 10,000,000$

$\$ 10,000,001-\$ 20,000,000$

Greater than $\$ 20,000,000$

Missing data

Total

\begin{tabular}{cc} 
Number & Percent \\
26 & 16.9 \\
43 & 27.9 \\
55 & 35.7 \\
14 & 9.1 \\
11 & 7.2 \\
5 & $\quad 3.2$ \\
$\underline{154}$ & $\underline{100.0}$ \\
\hline
\end{tabular}

Respondents were asked what percent of contact with their accounting firm was related to auditing, consulting, tax services, and financial statement preparation, respectively. As reported in Table 3, respondents used their accounting firm for a wide variety of services.

\section{Table 3 Type of Contact with Participating Clients}

$\underline{\text { Type of Client }}$

Predominantly audit

Predominantly tax

Predominantly financial statement preparation

Predominantly consulting

Uses several services

Missing data

Total

\begin{tabular}{cr} 
Number & Percent \\
\hline 28 & 18.2 \\
57 & 37.0 \\
21 & 13.6 \\
6 & 3.9 \\
38 & 24.7 \\
$\frac{4}{\underline{154}}$ & $\underline{2.6}$ \\
\hline
\end{tabular}


Tables 4 through 8 summarize the position, experience, gender, age, and education level of the person within each client firm who answered the survey. Individual respondents held a variety of positions in their firms and had diverse experience and educational backgrounds. In general, however, the individual respondents were experienced professionals who held positions of authority in their company. The wide range of client firms and individual respondents included in the data analysis improves the generalizability of our results.

\section{Table 4 Position of Individual Respondent}

$\underline{\text { Position }}$

Owner/General Manger

President/CEO

Vice-President/CFO

Controller

Accounting Manager

Other

Missing data

Total

Table 5 Experience of Individual Respondent (Years in Industry)

Years of Experience

Less than 6

$6-9$

$10-15$

$16-20$

$21-30$

More than 30

Missing data

Total

\section{Table 6 Gender of Individual Respondent}

Gender

Female

Male

Missing data

$$
\text { Total }
$$

\section{Table 7 Age of Individual Respondent}

\author{
Age \\ Less than 40 \\ $40-49$ \\ $50-59$ \\ 60 or more \\ Missing data \\ Total
}

\begin{tabular}{cr}
$\frac{\text { Number }}{46}$ & Percent \\
\hline 52 & 39.9 \\
15 & 33.8 \\
19 & 9.7 \\
11 & 12.3 \\
8 & 7.1 \\
$\underline{3}$ & 5.2 \\
$\underline{\underline{154}}$ & $\underline{2.0}$ \\
\hline
\end{tabular}

$\begin{array}{cr}\text { Number } & \text { Percent } \\ 15 & 9.7 \\ 11 & 7.1 \\ 30 & 19.5 \\ 25 & 16.2 \\ 46 & 29.9 \\ 21 & 13.6 \\ 6 & 4.0 \\ \underline{\underline{154}} & \underline{\underline{100.0}}\end{array}$

Percent

33.8

\begin{tabular}{rr}
101 & 65.6 \\
1 & 0.6 \\
\hline 154
\end{tabular}

$\underline{154} \underline{\underline{100.0}}$ 


\section{Table 8 Education Level of Individual Respondent}

Education Level

High school graduate

Some college

College graduate

Some postgraduate study

Masters degree or more

Missing data

Total

\begin{tabular}{|c|c|}
\hline Number & Percent \\
\hline 12 & 7.8 \\
\hline 43 & 27.9 \\
\hline 55 & 35.7 \\
\hline 18 & 11.7 \\
\hline 24 & 15.6 \\
\hline 2 & 1.3 \\
\hline$\overline{154}$ & $\overline{100.0}$ \\
\hline
\end{tabular}

\section{Analysis Of Results And Discussion}

Reliability Analysis and Factor Analysis

The five dimensions of the SERVQUAL scale were subjected to both a reliability analysis and a factor analysis. Reliability scores for each dimension exceeded .84 and are reported in Table 9.

All elements of each dimension of service quality loaded on a single factor and explained at least $68.5 \%$ of the variance. Factor analysis results are reported in Table 10.

Table 9 Reliability Analysis

\begin{tabular}{|c|c|}
\hline Dimension of Service Quality & Reliability Coefficient \\
\hline Tangibles & .8480 \\
\hline Reliability & .8963 \\
\hline Responsiveness & .8449 \\
\hline Assurance & .8852 \\
\hline Empathy & .9128 \\
\hline
\end{tabular}

Table 10 Factor Analysis

\begin{tabular}{|l|c|c|}
\hline $\begin{array}{l}\text { Dimension of } \\
\text { Service Quality }\end{array}$ & Eigenvalues & $\begin{array}{c}\text { Percent of Variance } \\
\text { Explained }\end{array}$ \\
\hline Tangibles & 2.750 & $68.7 \%$ \\
\hline Reliability & 3.552 & $71.0 \%$ \\
\hline Responsiveness & 2.739 & $68.5 \%$ \\
\hline Assurance & 2.983 & $74.6 \%$ \\
\hline Empathy & 3.717 & $74.3 \%$ \\
\hline
\end{tabular}

\section{The Relationship of Service Quality to Satisfaction}

We added the five measures of relationship satisfaction to arrive at an overall satisfaction score. Similarly, we added the individual components of each dimension of service quality (tangibles, reliability, responsiveness, assurance, and empathy) to arrive at an overall score for each dimension. The high reliability coefficients and the fact that the individual elements of each dimension of service quality loaded on a single factor made it appropriate to use summated measures of each dimension of service quality in data analysis. The overall scores for each of the five service quality dimensions were then regressed against the overall satisfaction score to test whether service quality is related to client satisfaction. The results are reported in Table 11 . Service quality explains $55.4 \%$ of the variation in client satisfaction. This supports Hypothesis One and provides evidence that service quality is positively related to client satisfaction in an accounting firm setting. 
The positive relationship between service quality and client satisfaction did not vary as a function of the either the type of services performed (e.g., audit, tax, financial statement preparation, or consulting) or the personal characteristics (position in the firm, years of experience, gender, age, or education level) of the individual respondents.

Table 11 Regression of Service Quality to Satisfaction (Total Satisfaction Score as the Dependent Variable)

\begin{tabular}{|c|c|c|c|c|c|}
\hline & $\begin{array}{l}\text { Unstandardized } \\
\text { Coefficients }\end{array}$ & $\begin{array}{l}\text { Standard } \\
\text { Error }\end{array}$ & $\begin{array}{l}\text { Standardized } \\
\text { Coefficients }\end{array}$ & $\frac{\text { t-Statistic }}{101}$ & $\underline{\text { Sig. }}$ \\
\hline (Constant) & .179 & $\overline{1.785}$ & & .101 & .920 \\
\hline Tangibles & .173 & .110 & .109 & 1.581 & .116 \\
\hline Reliability & .419 & .094 & .400 & 4.461 & $.000 *$ \\
\hline Responsiveness & 4.414E-02 & .093 & .037 & .475 & .636 \\
\hline Assurance & .332 & .134 & .221 & 2.479 & $.014 * *$ \\
\hline Empathy & .130 & .071 & .136 & 1.820 & .071 \\
\hline
\end{tabular}

* Significant at the .001 level.

** Significant at the .05 level.

\begin{tabular}{|c|c|c|c|}
\hline \multicolumn{4}{|c|}{ Model Summary: } \\
\hline$\frac{\mathrm{R}}{755}$ & $\frac{\text { R Square }}{570}$ & $\begin{array}{l}\text { Adjusted R } \\
\text { Square }\end{array}$ & $\begin{array}{l}\text { Standard } \\
\text { Error }\end{array}$ \\
\hline .755 & .570 & .554 & 2.35928 \\
\hline
\end{tabular}

The reliability dimension of service quality was significant at the .001 level. The assurance dimension was significant at the .05 level. The tangibles, responsiveness, and empathy dimensions were not significant.

These results suggest that accounting firms should concentrate their efforts on the items comprising the reliability and assurance dimensions of service quality. The finding of no results for the tangibles factor is consistent with prior research on professional service firms (Turner, Aldhizer, and Shank, 1999). In fact, some researchers eliminate the tangible component of the SERVQUAL scale when dealing with professional service firms, including accounting firms (see Behn, Carcello, Hermanson, and Hermanson, 1997).

The finding that accounting firm clients view reliability as the most important dimension of service quality is consistent with research in other settings. According to Berry and Parasuraman (1992), reliability is the most important criterion in evaluating service quality. Reliability has consistently been found to be significantly associated with client satisfaction with professional service firms (see e.g., Turner, Aldhizer, and Shank, 1999).

In order to determine whether accounting firms can benefit from concentrating their efforts on particular elements of reliability, we regressed the individual components of the reliability dimension on client satisfaction. The results are reported in Table 12 . 
Table 12 Regression of Service Quality to Satisfaction Analysis of Reliability Components of Service Quality

(Constant)

Keeps Promises

Sympathetic and reassuring

Dependable

Provides services at times

promised

Keeps records accurately

* Significant at the .01 level.

\begin{tabular}{l}
$\begin{array}{c}\text { Unstandardized } \\
\text { Coefficients }\end{array}$ \\
\hline 5.831 \\
.893 \\
.889 \\
.911
\end{tabular}

$-3.619 \mathrm{E}-02$

1.051

Standard
$\begin{gathered}\text { Error } \\ 1.346 \\ .520 \\ .326 \\ .521 \\ .559 \\ .384\end{gathered}$

Model Summary:

Adjusted R Square

.488
Standardized Coefficients

\begin{tabular}{lcc} 
& t-Statistic & Sig. \\
\cline { 2 - 3 } & 4.331 & .000 \\
.226 & 1.718 & .088 \\
.204 & 2.725 & $.007^{*}$ \\
.185 & 1.748 & .083 \\
& & \\
-.008 & -.065 & .948 \\
2.734 & 2.734 & $.007^{*}$
\end{tabular}

\begin{tabular}{|c|c|c|c|}
\hline & & Adjusted R $\underline{\text { Square }}$ & Standard \\
\hline$\underline{\mathrm{R}}$ & $\underline{\mathrm{R} \text { Square }}$ & & Error \\
\hline .711 & .505 & .488 & 2.5508 \\
\hline
\end{tabular}

Reliability consists of both the dependability and accuracy components (Berry and Parasuraman, 1992). The item dealing with accuracy (keeps records accurately) is significant, while those dealing with dependability are only marginally significant. It appears that accuracy is of paramount concern to accounting firm clients. The sympathetic and reassuring component of reliability was also significant.

We also regressed the individual components of the assurance dimension on client satisfaction. The results are reported in Table 13.

Table 13 Regression of Service Quality to Satisfaction Analysis of Assurance Components of Service Quality

(Constant)

Can trust employees

Can feel safe in

transactions

Employees are polite

Have knowledge to answer questions

* Significant at the .001 level.

\begin{tabular}{l} 
Unstandardized \\
Coefficients \\
\hline 4.035 \\
.621 \\
.910 \\
.602 \\
1.859
\end{tabular}

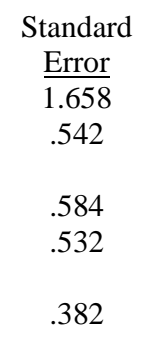

\begin{tabular}{c}
$\begin{array}{c}\text { Standardized } \\
\text { Coefficients }\end{array}$ \\
\hline .123 \\
.172 \\
.105 \\
.387
\end{tabular}

$\frac{\mathrm{t}-\text { Statistic }}{2.434}$
1.146
1.560
1.132

$\underline{\text { Sig. }}$ .016 .254 .121 .259 $.000 *$

$\begin{array}{lccc} & & \text { Adjusted R } \underline{\text { Square }} & \begin{array}{c}\text { Standard } \\ \text { Error }\end{array} \\ .681 & \frac{\mathrm{R} \mathrm{Square}}{.463} & \mathbf{. 4 4 9} & 2.6408\end{array}$

The only individual component in the assurance dimension of service quality that was significant was whether the accounting firm has the knowledge necessary to answer questions. Components dealing with trust and politeness were not significant. The results on the trustworthy component, however, may have to be reexamined in light of the crisis in public confidence created by Arthur Andersen's role in the Enron scandal. 


\section{The Relationship of Service Quality to Client Conflict}

We added the four measures of conflict to arrive at an overall conflict score. The overall scores for each of the five service quality dimensions (discussed earlier) were regressed against the overall conflict score to test Hypothesis Two. The results are reported in Table 14 . Service quality explains $29.1 \%$ of the variation in accounting firm/client conflict. The sign of the coefficients is in the expected direction. This is consistent with Hypothesis Two. Service quality is negatively related to accounting firm/client conflict. The negative relationship between service quality and firm/client conflict held for all client sizes, industries, service products, and respondent positions at the client firms.

Table 14

Regression of Service Quality to Accounting Firm/Client Conflict (Total Conflict Score as the Dependent Variable)

(Constant)

Tangibles

Reliability

Responsiveness

Assurance

Empathy

*Significant at the .05 level.

\section{Standardized}

Unstandardized

$\underline{\text { Coefficients }}$

18.725

$-1.653 \mathrm{E}-02$

$-3.884 \mathrm{E}-02$

$-.247$

$-.288$

$-.129$

\section{Coefficients}

1.934

.119

.102

.101

.145

.078

\begin{tabular}{c}
$\mathrm{t}$-statistic \\
\hline 9.681 \\
-.139 \\
-.381 \\
-2.446 \\
-1.980 \\
-1.664
\end{tabular}

$-.012$

$-.043$

$-.242$

$-.224$

$-.158$
Sig.

.000

.890

.704

$.016^{*}$

$.050 *$

.098

\begin{tabular}{|c|c|c|c|}
\hline \multicolumn{4}{|c|}{ Model Summary } \\
\hline$\frac{\mathrm{R}}{561}$ & $\frac{\text { R Square }}{315}$ & $\begin{array}{l}\text { Adjusted R } \\
\text { Square } \\
01\end{array}$ & $\begin{array}{l}\text { Standard } \\
\text { Error }\end{array}$ \\
\hline .561 & .315 & .291 & 2.55445 \\
\hline
\end{tabular}

The responsiveness and assurance dimensions of service quality were significant at the .05 level. The tangibles, reliability, and empathy dimensions were not significant.

In order to determine whether accounting firms can minimize accounting firm/client conflict by concentrating their efforts on particular elements of responsiveness or assurance, we regressed the individual components of these dimensions on accounting firm/client conflict. Our analysis of the individual components of the responsiveness dimension of service quality is reported in Table 15.

The assurance dimension of service quality should be of particular concern to accounting firms. Assurance was the only dimension of service quality that was significant in both the relationship of service quality to client satisfaction and the relationship of service quality to firm/client conflict.

The only component of the assurance dimension of service quality that was significant when regressed on accounting firm/client conflict was whether the accounting firm has the knowledge necessary to answer questions. Knowledge was also the only component that was significant when the assurance dimension of service quality was regressed on client satisfaction. Knowledge appears to be an important factor in both client satisfaction and accounting firm/client conflict. Clients demand that their accounting firms be knowledgeable of an ever-changing array of rules and regulations. Accounting firms should strive to provide their employees with the continuing professional education necessary to correctly respond to whatever technical issues may arise. 
Table 15

Regression of Service Quality to Firm/Client Conflict Analysis of Responsiveness Components of Service Quality

Unstandardized Standard Standardized

Coefficients $\quad$ Error $\quad$ Coefficients

2.189

$\frac{.617}{.610}$

$\underline{\text { Coefficients }}$

(Constant)

.539

.282

.182

$\frac{\mathrm{t}-\text { Statistic }}{3.545}$

$\underline{\text { Sig. }}$

Does not tell clients when

services performed

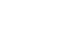

prompt service from employees

.289

.359

.088

1.914

.058

Employees not willing to

help

1.060

.493

.401

.251

.804

.422

.130

.037

2.151

.325

$.033^{*}$

* Significant at the .05 level.

\begin{tabular}{|c|c|c|c|}
\hline \multicolumn{4}{|c|}{ Model Summary } \\
\hline$\underline{\mathrm{R}}$ & $\underline{\text { R Square }}$ & Adjusted R Square & $\begin{array}{c}\text { Standard } \\
\text { Error }\end{array}$ \\
\hline .461 & .212 & 191 & 2.77039 \\
\hline
\end{tabular}

Whether employees are willing to help was significant at the .05 level. Telling clients exactly when services are performed was moderately significant. The components of responsiveness dealing with timeliness (receiving prompt service and responding to client requests promptly) were not significant. Accounting firms can reduce accounting firm/client conflict by demonstrating a willingness to assist clients in meeting their goals.

The regression of the individual components of the assurance dimension of service quality on accounting firm/client conflict is reported in Table 16.

Table 16

\begin{tabular}{|c|c|c|c|c|c|}
\hline \multicolumn{6}{|c|}{ Regression of Service Quality to Firm/Client Conflict Analysis of Assurance Components of Service Quality } \\
\hline & Unstandardized & Standard & Standardized & & \\
\hline & $\underline{\text { Coefficients }}$ & $\underline{\text { Error }}$ & $\underline{\text { Coefficients }}$ & $\underline{\mathrm{t}-\text { Statistic }}$ & $\underline{\text { Sig. }}$ \\
\hline (Constant) & 16.213 & 1.687 & & 9.609 & .000 \\
\hline Can trust employees & -.771 & .550 & -.179 & -1.401 & -.391 \\
\hline Can feel & & & & & \\
\hline transactions & .466 & .593 & .103 & .787 & .433 \\
\hline Employees are polite & -.773 & .541 & -.157 & 11.429 & .155 \\
\hline $\begin{array}{l}\text { Have knowledge to answer } \\
\text { questions }\end{array}$ & -1.340 & .388 & -.326 & -3.455 & $.001 *$ \\
\hline
\end{tabular}

\begin{tabular}{lccc}
\multicolumn{4}{c}{ Model Summary } \\
& & \\
& & Adjusted R $\underline{\text { Square }}$ & Standard \\
.499 & $\frac{\text { R Square }}{.249}$ & $\mathbf{2 2 8}$ & $\frac{\text { Error }}{2.6814}$
\end{tabular}

\section{Conclusion}

In conclusion, accounting firms can increase client satisfaction by concentrating on items that traditionally set certified public accountants apart from other professional firms - reliability and assurance. Accounting firms 
must be dependable. Providing accurate answers is a more important factor in client satisfaction than providing timely service. Accounting firms should also take steps to ensure that their employees are sympathetic and reassuring to clients.

Accounting firms can decrease accounting firm/client conflict, which can be detrimental to client relationships, by concentrating on responsiveness and assurance. Assurance is a significant factor in both client satisfaction and firm/client conflict. Knowledge is the most important component of assurance for both client satisfaction and accounting firm/client conflict. Therefore, accounting firms should strive to be as current as possible on accounting regulations and make sure their clients are aware of their level of knowledge. They should stress continuing education to ensure they are providing clients with accurate, up-to-date advice.

\section{References}

1. Behn, B., J. Carcello, D. Hermanson, and R. Hermanson. 1997. The determinants of audit client satisfaction among clients of Big Six firms. Accounting Horizons, (March): 7-24.

2. Berry, L., and A. Parasuraman. 1992. Marketing Services: Competing Through Quality, New York: The Free Press.

3. Bojanic, D.1991. "Quality Measurement in Professional Service Firms". Journal of Professional Services Marketing, 7, 2: 27-36.

4. Bowersox, D, B. Cooper, D. Lambert, and D. Taylor. 1980. Management in Marketing Channels. New York: McGraw-Hill Company.

5. Cronin, J., Jr., and S. Taylor. 1992. "Measuring service quality: A reexamination and extension”. Journal of Marketing, 56, 3: 55-68.

6. Freeman, D., and J. Dart. 1993. "Measuring the perceived quality of professional business services". Journal of Professional Marketing Services, 9, 1: 27-47.

7. Hoffman, D., and J. Bateson. 1997. Essentials of Service Marketing. Fort Worth, TX: The Dryden Press.

8. Parasuraman, A., L. Berry, and V. Zeithaml. 1988. SERVQUAL: "A multiple-item scale for measuring customer perceptions of service quality". Journal of Retailing, 64, 1: 12-40.

9. Parasuraman, A., V. Zeithaml, and L. Berry. 1985. "A conceptual model of service quality and its implications for future research". Journal of Marketing, 49, 4: 41-50.

10. Teas, R. 1994. "Expectations as a comparison standard in measuring service quality: An assessment of a reassessment". Journal of Marketing, 58, 1: 132-139.

11. Turner, L., G. Aldhizer III, and M. Shank. 1999. "Client perceptions of MAS quality as measured by a marketing-based service quality model". Accounting Horizons, 13, 1: 17-36.

12. Weekes, D., M. Scott, and P. Tidwell. 1996. "Measuring quality and client satisfaction in professional business services". Journal of Professional Services Marketing, 14, 2: 25-37. 
Notes 